\title{
O MÉTODO PSICANALÍTICO APLICADO À PESQUISA SOCIAL: A ESTRUTURA MOEBIANA DA ALTERIDADE NA POSSESSÃO
}

\author{
THE PSYCHOANALYTICAL METHOD \\ APPLIED TO SOCIAL RESEARCH: THE MOEBIAN STRUCTURE \\ OF ALTERITY IN POSSESSION \\ EL MÉTODO PSICOANALÍTICO APLICADO \\ A LA INVESTIGACIÓN SOCIAL: LA ESTRUCTURA MOEBIANA \\ DE LA ALTERIDAD EN LA POSESIÓN \\ Daniela Bueno de Oliveira Américo de Godoy* \\ José Francisco Miguel Henriques Bairrão**
}

\section{Resumo}

Tendo por finalidade explorar possibilidades de aplicação do método psicanalítico além da prática clínica, este trabalho propóe uma interpretaçáo topológica lacaniana do fenômeno da possessão na umbanda. Visa-se apreender o sujeito para além do psiquismo individual, de forma que o espaço subjetivo compreenda - continuamente - a transição de identidades ocorrida no corpo do médium. Isso se sustenta pela concepção de que o sistema interpretativo (que organiza a relação entre o mundo dos espíritos e o mundo dos vivos) e o sujeito coexistem em uma mesma estrutura. Para tanto, parte-se do conceito de significante, por ele ser capaz de criar uma rede de sentidos em função do efeito de um dizer inconsciente. Mediante um estudo de caso, mostra-se como, na possessão, o sujeito - concomitantemente suposto agente e efeito da combinatória significante - apresenta-se tanto como médium quanto como espíritos possuidores, os quais constituem o avesso e o direito de uma estrutura unilateral.

Palavras-chave: psicanálise e cultura; possessão; umbanda; alteridade.

\footnotetext{
* Universidade de São Paulo, Ribeirão Preto, SP, Brasil.

** Universidade de São Paulo, Ribeirão Preto, SP, Brasil.
} 


\section{Abstract}

Aiming to explore application possibilities of the psychoanalytical method farther than the clinical practice, this work proposes a Lacanian topological interpretation of the possession phenomenon in Umbanda. The subject is sought beyond the individual psychism in a way that the subjective space continually comprehends the identities transition occurred in the medium's body. This idea is sustained by the conception that the interpretative system (that organizes the relationship between the world of the spirits and the world of the livings) and the subject coexist in the same structure. Therefore, it starts from the concept of significant, as it is capable of creating a net of meanings according to the effect of an unconscious saying. Through a case study, it is shown how the subject, concomitantly supposed agent and effect of the significant combinatory, is presented in the possession as medium and as possessor spirits, which constitute the front side and the verso side of a unilateral structure.

Keywords: psychoanalysis and culture; possession; Umbanda; alterity.

\section{Resumen}

Teniendo por finalidad emplear posibilidades de aplicación del método psicoanalítico además de la práctica clínica, este trabajo propone una interpretación topológica lacaniana del fenómeno de la posesión en la umbanda. Se busca aprehender el sujeto más allá del psiquismo individual, de modo que el espacio subjetivo comprenda - continuamente - la transición de identidades ocurrida en el cuerpo del médium. Eso se sostiene por la concepción de que el sistema interpretativo (que organiza la relación entre el mundo de los espíritus y el mundo de los vivos) y el sujeto coexisten en una misma estructura. Para tanto, se parte del concepto de significante, por este ser capaz de crear una red de sentidos en función del efecto de un decir inconsciente. Mediante un estudio de caso, se muestra, como en la posesión, el sujeto - concomitantemente supuesto agente y efecto de la combinatoria significante - se presenta tanto como médium como también como espíritus poseedores, los cuales constituyen el revés y el derecho de una estructura unilateral.

Palabras clave: psicoanálisis e cultura; posesión; umbanda; alteridad.

\section{Introduçáo}

Diversas abordagens antropológicas compartilham a concepção de que diferentes "eus" podem conviver em um mesmo corpo, sem que isso necessariamen- 
te corresponda a uma psicopatologia - temática norteadora de diversos estudos psicológicos e psiquiátricos (Giumbelli, 1997; Almeida, Oda \& Dalgalarrondo, 2007; Moreira-Almeida \& Cardeña, 2011).

Também há trabalhos psicanalíticos sobre a possessão em cultos afro-brasileiros (La Porta, 1979; Quinet, 1989; Alberti, 1998; Chemama, 1999; Ferreto, 1999; Kracke, 2000; Fleig, 2003). Porém, como estes estudos em geral aplicam às vivências de possessão chaves de leituras derivadas do contexto do consultório clínico $^{1}$, as consideraçóes feitas, por vezes, situam a possessão no campo do diagnóstico. A análise é reduzida à personalidade do médium, relegando a segundo plano a dimensão da alteridade, do social e do interpessoal (Lambek, 1981), que atravessa e também se enuncia nessas experiências.

Para além de discussóes que partem de uma suposta psicopatologia relativa à possessão, Augras (1983) é uma psicóloga pioneira em estudos que situam a experiência do transe ao mesmo tempo como alteridade e como identidade, ao afirmar que é sendo outro que a unidade se constrói por meio do estabelecimento de uma duplicidade que, paradoxalmente, sintetiza o diferente e o idêntico. Neste sentido, o fenômeno da possessão deixa de ser analisado em função de comparaçóes etnocêntricas para ser tratado como um sistema de coerência intrínseca.

Como acreditamos que o método psicanalítico $^{2}$, ao lidar com experiências sociais e culturais, pode ir além da ilustração da psicologia individual, por meio de um estudo de caso, exemplificamos como a psicanálise pode ser aplicada ao cálculo das operaçôes simbólicas que estruturam a possessão sem reduzir o seu enunciado e a sua complexidade a uma espécie de sintoma psíquico. Com isso, visa-se contribuir para uma aplicação da psicanálise em pesquisa social cujo compromisso seja dar ouvidos às enunciações nos próprios termos de origem, ou seja, respeitando os critérios sociais e os padróes culturais que as modulam.

Crapanzano (1977, p. 12) referencia-se a uma citação proferida na África Ocidental de que "como nós não sabemos exatamente a localização de nosso pensamento podemos colocá-lo onde quisermos" para apresentar a ideia de que a pessoa, a sua relação com o mundo exterior e com o seu mundo interior, é uma construção social e cultural. Leiris (1958/1996, p. 950) afirma que os espíritos possuidores funcionam como "um tipo de vestuário de personalidades" o qual oferece repertório corporal diverso. Wolputte (2004) baseia-se no transe de possessão para questionar o conceito de individualidade como equivalente a uma única subjetividade para cada corpo. Augé (1988) aponta que na possessão a relação entre homens e deuses se dá num plano horizontal, pelo compartilhamento da mesma superfície simbólica por meio de uma convivência corporal cotidiana, na qual estes gozam de uma autonomia interna. 
Mas, como fundamentar o estatuto do corpo e da subjetividade na possessão de forma que vários "eus" promovam uma articulação espacial contínua entre o dentro e o fora, entre o sujeito ${ }^{3}$ e o Outro ${ }^{4}$, de forma que se possa dispensar a geometria euclidiana e assim diferenciar a geometria do eu da topologia do sujeito?

$\mathrm{O}$ recurso à teoria lacaniana permite equacionar topologicamente esse trânsito em função do trajeto significante (suporte material capaz de representar o sujeito para outro significante mediante uma cadeia simbólica), o qual produz o sujeito como efeito de um dizer inconsciente, em função daquilo que "falta à sua disposição para restabelecer a continuidade de seu discurso consciente" (Lacan, 1953/1998, p. 260). Isso implica considerar que as formaçóes do inconsciente se produzem na superfície do discurso corrente. No nível da enunciação, não há distinção entre avesso e direito; o inconsciente se mostra nas entrelinhas do dizer, continuamente a ele. É somente com o corte que ele se revela o avesso do discurso, que fica esquecido por detrás do dito (Lacan, 1972/2001).

A aplicação da topologia lacaniana às relaçôes de alteridade estabelecidas pelo sistema umbandista visa - ao esquematizar as relaçóes significantes que apontam para a estrutura do dizer (inconsciente) - propor um novo tipo de temporalidade e de espacialidade ao horizonte analítico da possessão. No momento em que se concebem retroaçóes, inversóes, interrupçóes e redundâncias em função dos trajetos significantes nas superfícies topológicas, torna-se possível trabalhar com a história e com a estrutura concomitantemente (Vappereau, 1988).

Enquanto a concepção kantiana afirma o tempo como uma forma de sentido interno e o espaço como uma forma de sentido externo, ambos formas fundamentais e a priori da intuição, a concepção topológica concebe o primeiro inserido no segundo. O espaço não se encontra fora do sujeito, é o próprio dinamismo estrutural encarnado no corpo; e o tempo aparece em função de relaçóes retroativas apercebidas devido à repetição que ocorre como índice significante.

\section{Metodologia}

Para exemplificar o potencial metodológico da psicanálise aplicada em contextos socais, procede-se a um estudo de caso realizado com uma médium de umbanda - Barbara ${ }^{5}$ - e com um de seus outros espirituais - Cabocla Águia Dourada - mediante encontros viabilizados por meio da "escuta participante" (Bairrão, 2005; Godoy, 2012).

O método psicanalítico sustenta-se no domínio da escuta, que não se resume à audição estrito senso, visto que toda ação intrinsecamente consistente de 
sentido é veículo da significância (Bairrão, 2004). Assim, dizer não é necessariamente falar, pois o dito se apresenta por meio de diversas formas discursivas.

No âmbito da estrutura, trocar "observação" por "escuta” ultrapassa a mera diferenciação perceptiva, na medida em que psicanaliticamente é possível ver com as mãos (Dolto \& Nasio, 1991) comer com os olhos (Quinet, 2002) e, como sugere Bairrão (2011) no caso da possessão, ver com o corpo inteiro.

Para tanto, o pesquisador deve colocar-se numa posição eliciadora de enunciaçóes (no caso, provenientes do campo), no intuito de testemunhar o que lhe é dito e, assim, favorecer que o outro possa se revelar em seus próprios termos. Neste sentido, o "escutar" propicia a interpretação não em função de uma atribuição de significados e de uma sobreposição de explicações a falas, atos, gestos, etc., mas em função de uma restituição do saber inconsciente do outro, de modo que se dê ouvidos e se recupere o que verdadeiramente se diz na repetição significante, sem o encobrir com as consideraçóes do ego do pesquisador.

Logo, o lugar do pesquisador, entendido em função do referencial psicanalítico, decorre da transferência que cria um único espaço onde o inconsciente se atualiza, ou seja, este não é pessoal, assim como seus produtos não o são. Lacan (1951/1998) propóe que se interprete na transferência (colaborador e pesquisador encontram-se em um mesmo espaço subjetivo) e não $a$ transferência (o que implicaria uma posição fora da estrutura).

A trama significante, irredutível ao médium ou ao seu outro espiritual, pode, então, ser analisada por meio de uma escuta que a remete a pontos nodais, responsáveis pela tessitura significante que conecta pessoa e espírito de modo contínuo. Mais especificamente, "escutar o social” visa apresentar as cadeias significantes que, apreendidas em termos de superfície, favorecem o entendimento de um sujeito plural ou coletivo, uma vez que, as reorganizaçóes - cortes -, mesmo modificando a configuração original daquelas cadeias, atestam a estrutura moebiana da subjetividade.

Isso implica a possibilidade de que o outro possa aparecer como sujeito da enunciação, posto que conforme a teoria lacaniana o conceito de sujeito não se confunde com o de pessoa ou o de indivíduo. Logo, esta função não precisa ser preenchida necessariamente pela pessoa do médium, visto que o sujeito é suposto em função de um mesmo discurso produzido por meio de diferentes versóes de um texto (Vappereau, 1988). No caso, médium e entidades comporiam estas diferentes versões do mesmo.

Neste sentido, compreendem-se os espíritos (aqui em questão: a entidade denominada Cabocla Águia Dourada) como ao mesmo tempo pertencentes ao campo do Outro e à subjetividade do médium. Tratar os espíritos como outros 
que assumem a posição de sujeito da enunciação significa supor um espaço em que seja possível transformar o avesso em direito, de forma contínua, o que ocorre no ponto de torção de estruturas moebianas.

No entanto, um não se confunde com o outro. Apenas os significantes são comuns a eles, fazendo com que sua repetição marque os mesmos traços na médium e em seus outros espirituais. Por outro "lado", justamente por não se resumirem a uma função psíquica da médium, os espíritos apresentam-se como metáforas sociais culturalmente eloquentes. Barbara e Cabocla Águia Dourada são, portanto, dois "seres" socialmente distintos, mas constituídos continuamente, o que favorece a compreensão de que o psíquico e o social não podem ser analisados disjuntamente.

\section{Resultados e Discussão}

Segundo a doutrina umbandista em que esta médium se formou, os orixás se manifestam como forças da natureza associadas aos quatro elementos (ar, água, terra e fogo) e são manipulados pelos espíritos ao se utilizarem dos elementos. Neste artigo, há referência a seis orixás: Elegbara ou Exu (fogo), Iansã (ar e fogo), Iemanjá (água salgada), Oxum (água doce), Oxumaré (fogo e água) e Xangô (fogo e terra); os quais - combinados - aparecem no discurso da médium com a finalidade de investigar sua filiação espiritual. Ser nomeada como filha de um santo, de um orixá, assegurar-lhe-ia uma posição específica no terreiro e consequentemente um reconhecimento social, mas esta espera também encobria um conflito: o desejo por esta nomeação poderia ser uma armadilha para se submeter às imposiçóes do outro.

A revelação de uma associação com Iansã momentaneamente lhe deu a sensação de destaque social, mas também de aprisionamento, de estar condenada a ser uma única coisa, a qual paradoxalmente não condizia com Iansã como vento (que não para), nem como explosão (princípio do vento, que remete à combinação simbólica dos elementos "ar" e "fogo"):

Teve uma vivência de Iansã [...] como o princípio do vento, a explosão, e o pai de santo me disse que eu carregava essa Iansã, mas não me foi dito "você é filha de Iansâ", mesmo assim ficou a ideia de como eu sou, no sentido de movimento, que é de não parar. Tudo que eu queria era essa nomeação, eu achei que isso ia dar um basta e não deu. $\mathrm{O}$ efeito foi inverso, não foi uma revelação de orixá efetivo, mas querendo ou não foi uma 
nomeação, e perante outras pessoas, mas a euforia passou bem rápido, não foi um preenchimento de fato.

Com este acontecimento ela pôde perceber o conflito relativo a esta nomeação: por um lado o prazer relativo à atribuição de um lugar social e, por outro, a angústia de estar atrelada a um único orixá. No entanto, é essa sensação de aprisionamento que parece corroborar sua filiação: assim como o vento não pode parar, ela tem de ir em busca da liberdade que tanto anseia, razão pela qual não quer se sentir presa a nenhum orixá.

Talvez mais adequado do que formular esta questão em termos de conflito, que pressupóe uma resolução a favor de um ou outro polo, seja pensá-lo como um paradoxo que pode ser equacionado através da faixa de Moebius - superfície unilateral em que avesso e direito se encontram em continuidade, obtida pela união das extremidades de uma fita após a realização de uma semitorção na mesma. Aparentemente, haveria o lado do prazer pela ocupação de um lugar social de ser filha de Iansã e o seu avesso, relativo à angústia gerada por esta filiação. Mas, como a faixa é unilateral, esta diferenciação só pode ser pensada pontualmente, ou seja, é justamente esta condição (ser filha de Iansã) que explicaria o desejo de não estar vinculada a somente um orixá. Logo, este lugar estrutura seu ser comportando desejos antagônicos por ambos serem logicamente compatíveis.

Como não somos uma coisa só, uma única identidade, percebo a presença de vários orixás me compondo e estando presentes em minha vida. Estar aprisionada numa única denominação de ser filha de Iansã e pronto, de estar condenada a ser uma única coisa, é disso que não gosto. Mas, ao mesmo tempo, a nomeação de ser filha de Iansã também me confere um lugar social que eu gosto. Então, há um conflito não resolvido (e acho que nunca será) de ser nomeada.

Essa nomeação, vivida como um corte, permitiu o redirecionamento da responsabilidade de seus desejos e atos para si, pois ela já havia sido enunciada por suas entidades. Além da questão do reconhecimento social versus aprisionamento subjetivo por meio de significados atrelados a uma denominação, há também aquele referente à revelação que implica a aceitação de características marcantes de seu ser.

O Outro, através do dito, revela, pelo avesso, a própria mensagem emitida pelo sujeito, porém invertida: é o lado imperativo da lei que, articulado à estrutura (à linguagem), determina possibilidades de eleição de sentidos. Mas, como o 
assentimento de uma ordem é uma escolha, a palavra do Outro é um imperativo que sanciona a eleição do desejo: "Mas as entidades falam, elas já falaram de quem eu sou filha... eu também tenho Iansã, a Cabocla incorporava e já falava, a Iansã é a santa que eu carrego".

De fato, o que se aproxima de um desvendamento subjetivo são gestos de reconhecimento da própria natureza da médium, porque na umbanda os elementos da natureza metaforizam, em última instância, a pessoa. Dar-se conta desses elementos (significantes) em ato sustenta sentidos atrelados ao corpo, àquilo que transcende o mero significado relativo às palavras. É por isso que a médium afirma preferir ser dita filha do vento, do mar ou do fogo - elementos da natureza considerados como significantes que enodam, por meio de pontos de intersecção, semelhanças e diferenças entre ela e seus outros espirituais.

Outro dia, uma pessoa lá do templo disse assim: "e aí, filha do vento?”. Então tem um negócio que nunca ninguém fala mas aparece, "o vento chegou", algumas pessoas falam de Iemanjá para mim, tem gente que fala de Oxumaré, com tanta cobra para lá e para cá, e muitas falando de fogo, filha do fogo, isso é comum.

Esta relação, estruturalmente contínua, se estabelece e se desenvolve em um equilíbrio delicado no qual ora o sujeito ora o Outro (via outro) assume a posição de sujeito da enunciação. O Outro como campo de um discurso (no caso, das entidades ${ }^{6}$ ) que gera sentido para o sujeito - incluindo-o (o Outro abarca os significantes que representam o sujeito) e excluindo-o (mas esses significantes não o representam por completo, pois o Outro é furado) ao mesmo tempo deste universo - fornece a textura e a configuração do sujeito.

De qualquer modo, é pelo discurso do Outro, que não se dá apenas por palavras, que o sujeito - como efeito desse dizer - pode aparecer pela repercussão de traços estruturais comuns aos espíritos possuidores na vivência pessoal do médium. Para além do empírico da enunciação, a circulação significante entre pessoas e espíritos atesta que na possessão não se trata nem de uma alteridade radical - os espíritos não se encontram em exterioridade ao médium - nem de uma equivalência entre eles. Há pontos em comum que ao mesmo tempo os relacionam e os diferenciam.

Simbolicamente, a repetição de traços aponta para o núcleo pulsante que anima o dinamismo da estrutura. Como uma estrutura topológica pode apresentar-se de inúmeras maneiras porque não é a forma aparente que importa, mas sim suas características intrínsecas, esquematizar aquela repetição equivale a en- 
contrar os invariantes que - em termos de representação - podem ser diferentes, quando estruturalmente são iguais. Neste sentido, considerar os espíritos possuidores como outros "eus" é essencial para desvendar os "elementos significantes" do sujeito.

A partir do mapeamento significante fornecido pelo questionamento acerca da filiação espiritual da médium, que aponta para o vento (ar), o fogo e o mar (água) como seus principais elementos, apresentamos o outro espiritual de Barbara que os articula mais explicitamente.

\section{Cabocla Águia Dourada}

Esta entidade é, de fato, a que melhor articula todos os elementos significantes mencionados pela médium. Primeiramente, temos a relação entre deserto (terra e fogo) e água. Esta aparece como som, como imagem acústica de uma força da natureza que se refere à invasão da água do mar na água do rio (pororoca), caminho contrário ao percurso normalmente observado graças a forte presença dos ventos (ar).

A minha entidade diz que é árabe. Ela começou falando que ela era do deserto. Quando ela vinha, cantava uma língua estranha, mantras, e ao falar o nome dela na língua dela, ela disse que esse nome era o som da água voltando, o som mesmo, puramente o som [...] Desde o comecinho, ela falava do mar, e que trazia uma Iansã junto. Ela não dizia que ela trabalhava com a Iansã, porque ela não é uma Cabocla que trabalha com os ventos literalmente, mas que quando ela chega, a Iansã chega junto. Ela fala que ela é do Marrocos e que trabalha com a Iemanjá. Depois de muito tempo é que ela foi falar que este trabalho com a Iemanjá era na pororoca.

A explicação desta rede significante complexamente polissêmica provém da Cabocla, quase na forma de um enigma, de que maneira isso ocorre. Iansã é a força que comanda este encontro brutal, mas esperado, entre Iemanjá e Oxum: é pela inspiração, provocada pela lua fazendo a maré subir a ponto de avançar sobre o rio e fazendo transbordar de amor o coração daqueles que amam, que a Cabocla trabalha na pororoca:

Cabocla, diz que trabalha na pororoca, é pela lua. É ela que inspira... quando a Cabocla diz "eu trabalho na lua" é com o efeito que ela dá sobre as 
maré, através da inspiração dos amantes, daqueles que estão com o coração cheio de amor pelo mundo [...] No que sentem amor e paixão pelas estrela, muito pela lua, provoca um reboliço dentro do coração doceis... essa paixão provoca como efeito vontade de viver no coração de cada um; é onde a Cabocla trabalha.

Por um lado há o amor, que transforma o ser amado em lua, em inspiração, em entusiasmo poético. Porém essa insuflação de ânimo ou de ideias assenta-se metaforicamente no movimento respiratório de reter o ar - inspirar -, como se o ar fosse uma espécie de alimento espiritual, aquilo que a Cabocla chama de sua essência, ou seja, Iansã; cujo poder encontra-se tanto na inspiração, na brisa, nos ventos, como no encontro do ar com o fogo que gera uma explosáo: "O amor no coração faz a gente ficar quentinho, as pessoas que oceis amam é como se fosse a lua proceis. É por isso que Cabocla tá trabalhando com o ar, porque inspira oceis, ela tá na essência dela hoje”.

É por isso que também ela trabalha no choque, no encontro de diferentes emoçôes, não necessariamente com as águas. Trata-se do poder de Iansã de provocar explosões, tal como se manifesta uma paixão avassaladora, desenfreada:

Cabocla sempre fala de Iemanjá e Oxum porque são as duas grandes força da natureza que oceis pode ver, mas não quer dizer que é só lá que essa trabaia, quer dizer que é no choque do encontro das emoçôes. Ocê pode dizer que a Cabocla trabalha na essência da paixão.

Sobre este choque, a médium observa que aí se encontra a ligação com a esquerda (desenvolvida mais abaixo), o que corrobora seu entendimento de que os encantados ${ }^{7}$ podem trabalhar tanto na esquerda quanto na direita:

Mas o que a Cabocla diz é sobre o choque desse encontro, onde tem a encruzilhada (o choque dos encontros) é exatamente onde ela trabalha, não é exatamente a pororoca, mas onde tem o choque, que é justamente nas encruzilhadas. Quando você cruza um caminho com o outro e tem um conflito ali, um condensado de energia, na explosão do choque do encontro, é aí que ela trabalha, é aí que eu acho que tem o encontro com a esquerda.

Encontro entre a suavidade do amor com o arrebatamento da paixão, do divino com o terreno, da doçura com a sedução, da beleza com o desejo, a Ca- 
bocla Águia Dourada apresenta diversos aspectos do feminino, ou seja, como um encantado, ser uma Pomba-Gira também é uma de suas potencialidades:

Quem é a Cabocla Águia Dourada? Ocê olhou e viu isso: dois lenços amarrados (um dourado e outro vermelho com fios dourados, mais um cinto vermelho com medalhas douradas amarrado na cintura): é a cor do fogo, o brilho da Oxum (dourado), são as cores da Pomba-Gira. Tudo aquilo que veste, essa dá uma aparência que nem sempre as pessoas sabem entender, mas nem porque a Cabocla se veste ou não como uma Pomba-Gira, isso não importa, mas sim o efeito da ação do trabalho da entidade no coração doceis.

É interessante notar que a construção do relato da médium não é linear, embora seja bem amarrado, como toda enunciação inconsciente. Assim, depois de ter dito que a Cabocla vem do deserto, que trabalha com as águas (da pororoca), com o choque de encontros e com os ventos, a médium relata como lhe foi revelado o nome desta entidade:

[em uma entrega para Xangô] eu vi saindo de uma pedra, um pássaro que foi se fazendo assim, ele era marrom com amarelo e saía da pedra assim lá do alto e foi se fazendo pássaro... depois a Cabocla disse para me falarem que ela era o pássaro, disse que podiam confirmar para filha (eu) que o nome dela na umbanda ia ser Águia Dourada. Ela se mostrou para mim numa imagem, que era um pássaro saindo da pedra, que é Xangô. A Iansã tem uma ligação muito forte com Xangô.

Presentificado nas pedras e nos minerais, Xangô é entendido neste terreiro como a cristalização do fogo, das lavas vulcânicas, lugar de onde a Cabocla se dá a ver para sua médium como um encantado, um pássaro que condensa, por meio de uma produção onírica ${ }^{8}$, elementos do ar (Iansã) já que ele voa, e elementos do fogo associado à terra (Xangô).

No trecho a seguir, que narra sua vida e sua morte, nota-se tanto a presença de Iansã como a de Elegbara. Iansã porque a Cabocla foi uma mulher guerreira que defendia outras mulheres e crianças (entendidas como pessoas marginalizadas), procurando salvá-las da morte que chegaria com a guerra, porque de essência imaterial é o orixá encarregado de conduzir o espírito dos mortos e porque no momento de sua própria morte por uma espada transforma-se em águia que, agora pelo ar, continua a sua jornada de aconselhar as pessoas. 
A presença de Elegbara se dá pelo fato de ela ser uma mensageira, principal atributo deste orixá responsável pela comunicação entre os deuses e entre os homens e os deuses. Atrelado a esta função está o princípio do movimento, que no ar é bem mais rápido. Ou seja, a partir de sua história, Iansã e Elegbara revelam-se como os principais orixás da Cabocla.

A história dela é linda. Ela era mensageira ia nas tribos, nas aldeias antes da guerra chegar para avisar que a guerra estava chegando (é tudo uma construção, não foi assim de uma vez) ela dizia que quando ela chegava na aldeia ela avisava principalmente mulheres e crianças, ela levava a fé de Alá, para levar um pouco de esperança e para avisar para todo mundo sair. Era a Iansã que acompanhava ela, ou seja, não é ela a Iansã, ela [Iansã] ficava lá para levar o espírito das pessoas que morriam e ela [Cabocla] continuava a jornada de ser mensageira, ia para outra aldeia náo parava. Ia antes da guerra; e ela disse que um dia uma espada atravessou por trás dela, que foi como ela morreu, a espada atravessou e se transformou em um bico direcionado para cima, ela se transforma em águia e ela continua a levar a mensagem de Alá onde ela vai, que é através do canto, por isso que ela incorpora.

Segundo a médium, a Cabocla não é Iansã, mas possui uma forte ligação com este orixá, como com Iemanjá, que, além de se fazer presente nas águas da pororoca, aparece na trama subjetiva da médium desde cedo e reafirma-se no nome de diversas entidades:

Eu adorava água quando eu era criança, eu precisava nadar, nadar, nadar, precisava, era um desespero, eu achava que era filha de Iemanjá de tanto que eu nadava, mas era uma água meio vulcânica. Quando eu comecei a incorporar, eu parei de ter vontade de nadar, parece que Iemanjá veio até mim, que foi a minha Cabocla, aí sim a água acalmou, eu parei com essa vontade, equilibrou. Eu tenho várias entidades, Mário, Margarida, Marlene, Mariazinha, Vó Mariana, Mar, Mar, Mar. A explicação que o marinheiro deu uma vez foi que quando eu era pequena eu tinha uma ligação muito grande com Iemanjá mesmo, e uma forma de eles homenagearem Iemanjá foi eles virem com nome do mar.

Relata que, em sua infância, o desejo pelo mar, a sensação de ter a proteção de Iemanjá era muito forte, porém havia também a admiração pelo céu azul que, 
para ela, se relacionava à liberdade. Em pensamento, ao enfrentar dilemas hipotéticos como escolher entre exército, marinha ou aeronáutica; ou entre estar em um avião ou em um navio, ela sempre escolhia o ar, mas sentia que estava traindo Iemanjá, o primeiro orixá com quem se identificou.

Conta que apenas recentemente percebeu que ar está contido em mar, marca significante de uma trama na qual Iansã e Iemanjá combinam-se como figura e fundo principais de um mosaico subjetivo também formado por outras qualidades, como a relativa ao fogo (Elegbara).

No momento em que o mar pode ser subjetivado nos outros que constituem o seu ser, inscrevendo-se no nome de seus outros espirituais, a água que falta à médium passa a ter um lugar, mesmo que seja outro, já que não pertence a seu eu. Aquilo que sente como sendo seu é a irrupção do fogo, presente na imagem do vulcão. $\mathrm{O}$ que se repete em seu discurso, de diferentes maneiras, é essa dualidade como uma tentativa de sintetizar sem apagar essas forças opostas, encarnada no orixá Oxumaré, que também carrega o mar em seu nome:

Você já viu o vento parar? [pergunta feita pela Cabocla, que depois foi relatada para a médium]. Águia é o vento, é Iansã [...] A Iansã é livre, Oxumaré concilia os opostos e tudo que é contraditório e Elegbara porque é o fogo. Carrego Iansã que é essa ventania, mas a minha base é fogo e eu tenho que saber lidar com o fogo para me sentir incluída no mundo. Por isso que elas [as entidades] trabalham com a água, para contrabalancear, mas nessa função de auxiliar o fogo a ter uma função no mundo. $\mathrm{O}$ orixá que reina aqui é uma mistura de uma ventania meio nervosa com uma natureza de fogo minha, fogo neste sentido que é explosivo.

Neste trecho fica claro que a médium referencia seu ser ao fogo, oscilando entre uma força criativa e outra que, por ser potencializada pelo ar (vento), pode explodir a qualquer momento. Ao se colocar nesta mistura perigosa, a médium tem dificuldade de se sentir incluída no mundo, para que isso ocorra precisa administrar o fogo que carrega consigo, o qual aparece em seu temperamento intempestivo:

[A médium comenta com suas palavras uma fala da Cabocla]: Oxumaré, que é a cobra, tem sabedoria para andar num lugar quente. A cobra não se queima no deserto, ela sabe absorver a água, o pouco que tem e sabe andar sem se queimar. Esse jogo de cintura, esse andar com sabedoria no mundo, são várias metáforas de Oxumaré, de cobra, de andar. 
Para Barbara, Oxumaré é a possibilidade de conciliar / controlar sua essência (fogo) através da pouca "quantidade de água" que tem em si, de modo que, sem se negar, possa encontrar uma soluçáo de compromisso entre aquilo que ela é e aquilo que ela considera que deve ser. Se primeiramente a água apareceu como som, agora aparece como movimento associado à cobra. Oxumaré não é apenas um elemento simbólico capaz de relacionar significantes entre si, ele inscreve Iemanjá (mar) e Elegbara (fogo) no corpo da médium:

Quando ela [a Cabocla] entra nessa dança dela mexendo o ventre, fazendo um movimento de cobra, cheio de onda, eu sinto essa força grande, essa parte assim do ventre, que é a dança do ventre. Tem outro movimento, de Elegbara, que é de fazer assim com a mão [ela fecha as mãos, colocando uma sobre a outra e faz um movimento oscilatório bem rápido em direção a seu órgão genital], começa a vir um fogo, porque é muita energia.

No entanto, cabe ressaltar que a cobra (naja) é o animal no qual a sua Pomba-Gira - Margarida - se encantou. Tanto sua Cabocla quanto sua Pomba-Gira se relacionam ao mundo árabe e por isso dançam de forma semelhante, ou seja, foi devido à forma de dançar que remete diretamente à dança do ventre que a médium desconfiou que ambas poderiam ser uma mesma entidade. Mas a Pomba-Gira "faz" fogo ao dançar, não suaviza os movimentos.

A Pomba-Gira dá aquela realçada, elas [Pomba-Gira e Cabocla] têm uma semelhança assim. No começo eu achava que era uma entidade só, eu pensava que a Pomba-Gira tava disfarçando, só que a Pomba-Gira pega no fogão mesmo, ela dá uns paus, ela faz um oito (com a cintura) é mais pesado, é mais ativo.

A água aparece, portanto, como movimento: som, maré, onda, pororoca, dança do ventre; Iansã associada a Elegbara é que age sobre Iemanjá e Oxum. O resultado combinatório dessas possibilidades significantes condensa-se na figura de Oxumaré que, segundo a concepçâo do terreiro onde se desenvolveu, é o orixá da continuidade, da composição, do encontro.

Como dito anteriormente, a faixa de Moebius apresenta a continuidade estrutural que organiza esta subjetividade a partir da lógica simbólica umbandista, segundo a qual o vento (Iansã) não para, não sendo possível para a médium que se defina em relação a apenas um lugar. Em uma análise pontual, verifica-se a referência a cada um dos orixás, mas estruturalmente o deslizamento significante 
aponta para uma continuidade referencial: as características dos orixás se cruzam e se remetem umas às outras.

No corpo esta continuidade também se faz presente em um objeto (pedra vermelha) por meio do qual a Cabocla Águia Dourada trabalha: o sujeito ancora-se em qualquer materialidade que possa lhe oferecer alguma consistência, seja ela da ordem do símbolo, da carne ou do objeto. Esta entidade, ao trabalhar com Iansã, Iemanjá, Elegbara e Oxumaré, está igualmente elaborando representaçóes subjetivas que a médium tem de si, em última instância referenciadas ao fogo (a Elegbara) e ao ar (Iansã), porque, seja na água ou na terra (cristal, pedra), a Cabocla trabalha na explosão:

Ela trabalha com uma pedra vermelha que se chama granada (até a pedra explode!). Ela fala do fogo do centro da terra, que é Elegbara, com o qual ela trabalha, e Elegbara quando chega em mim, já não chega tão forte [...] a granada faz isso mesmo, ela amortece um pouco o impacto da energia que chega do chão para não atingir tanto a pessoa.

Por meio de sua Cabocla, o dizer inconsciente repercute para além de um solo metafórico capaz de produzir não apenas a identificação simbólica, mas também um tipo de identificação que estaria mais próxima de uma determinação subjetiva impossível de ser dita, apenas vivida e sentida no corpo da médium. "Fogo" - para além e aquém dos sentidos - aparece como a marca fundante mais reveladora do sujeito.

Deste modo, a partir de um caso, pode-se propor que os outros espirituais constituem diversos feixes de enunciação do sujeito. Tanto o médium quanto os espíritos seguem a lógica gramatical do Outro umbandista, o qual fornece o padrão simbólico e imaginário que sustenta o nó - ponto de amarração - em que o significante se recruza nos dois "lados" de uma superfície unilateral.

\section{Eu e outro: frente e verso de uma superfície unilateral}

Ao considerarmos que, na possessão, o inconsciente - como discurso do Outro - se apresenta por meio da faixa de Moebius, mais especificamente pela localização do ponto de torção, que, de fato, se encontra em qualquer parte da superfície, já que sua referência depende do percurso na estrutura, tem-se no discurso corrente uma distinção entre avesso e direito (médium e seus outros espirituais); porém, pela análise dos significantes comuns ao sujeito e ao outro, 
chega-se a estes pontos que, localmente, marcam a diferença, mas que estruturalmente possibilitam a continuidade entre estas instâncias.

O que na Barbara aparece como ato, como seu modo de ser e de agir, suas preferências - do tipo "eu gosto de lidar com o fogo" (acender velas, realizar o processo de defumaçáo) -, na Cabocla aparece como atributo pertencente aos elementos com os quais trabalha, ou seja, todo significante possui, ao mesmo tempo, um "lado" psíquico e outro social.

A continuidade característica da faixa de Moebius, possibilitada pela particularidade estrutural de unir avesso e direito em todos os seus pontos, mostra-se na cadeia significante tecida com os elementos originários do universo umbandista. Fogo, ar, água e terra são significantes que combinados entre si apresentam tanto a médium como o seu outro espiritual; ou seja, partindo de um mesmo ponto é possível deslizar para inúmeras direçôes.

As características de seus orixás mais próximos (Elegbara, Iansã, Iemanjá) tal como estabelecidas no específico contexto umbandista em que se desenvolveu, definem esta entidade e ressoam na Barbara. Iansã como princípio do vento, da explosão e do movimento aparece na Cabocla e em sua personalidade. Iemanjá aparece claramente nos nomes de outros espíritos - Mário, Margarida, Mariazinha -, além de ser o elemento que contrabalança o predomínio de fogo - Elegbara -; do mesmo modo que o elemento terra, responsável pelo seu amortecimento.

Um sentido desliza em outro e só assume contornos expressivos quando várias combinações são feitas. $\mathrm{O}$ corte ao meio da faixa de Moebius (em volta simples, longitudinal, que segue pela linha média da fita) a transforma em uma superfície bilateral, sem a desfazer em dois pedaços, pois ela continua sendo uma única faixa (Vappereau, 1988). Mesmo sem ser dois, o sujeito do inconsciente apresenta uma divisão que lhe é consubstancial (aqui presentificada na figura da Cabocla e do eu da médium), que revela o inconsciente como organizador de um dizer comum a diferentes "eus" (os dois lados da faixa cortada), o qual só agora é posto em evidência. Antes do corte o inconsciente encontrava-se oculto no dito.

Se o discurso corrente produz a imagem de que há médium e entidades, cada um de um lado da faixa, o corte (a análise) sugere que inicialmente eles são contínuos, tornando-se apenas avesso e direito um do outro (como resultado do corte acima mencionado), porém ainda em uma mesma estrutura. $\mathrm{O}$ corte marca a separação dos deslizamentos significantes relativos a uma mesma posição estrutural, daí a médium falar que as suas entidades ou se manifestam por afinidade ou para compensar algo que lhe falta.

No enredo da história da Cabocla, "fogo" se repete das mais diversas formas como aquilo que é simbólico e também real, encontrando-se, portanto, na 
fronteira da significância. Segundo o pai de santo, o ser Barbara seria regido principalmente por Iansã (ar), quando de fato a repetição significante (deserto, aridez, dourado, vermelho, granada, pororoca, ventre, etc.) contorna um vazio cuja borda significante é "fogo" e "fogo" combinado com "ar".

Isso se verifica ao considerarmos o nome da Cabocla relativamente ao material significante obtido. Há um tipo de equivalência sonora (e, portanto, significante) entre águia e água que remete a uma relação entre Iansã (ar) e Iemanjá (água). Barbara fala que a águia é o vento (Iansã) e a água aparece tanto no nome deste espírito que, na "língua dela" é o som da água voltando (ressaca?), quanto na história de vida da médium que, quando pequena, tinha uma ligação muito forte com o mar, com Iemanjá. Além disso, ia é o som que a Cabocla faz ao incorporar. O som da água está no seu nome e é seu som característico também.

Essa relação aponta para uma questão fundamental quanto ao mais medular da médium, visto que ela mesma comentou que o ar estava contido em mar, ou seja, ela conseguiu elaborar um lugar comum para duas instâncias distintas.

Iemanjá ficou ao fundo (aparecendo disfarçada nos nomes das entidades) e Iansã fez-se figura. A Cabocla trabalha na pororoca, no choque, no movimento das marés, que poeticamente pode ser descrito como um movimento de inspiração e expiração realizado no mar. Essa relação também se inscreve no seu lugar de origem: Marrocos, no qual pode ser lido Marrocos, ou seja, um mar vazio de água e cheio de ar e também Mar-rocos, aludindo ao fato de que a voz (uma forma sensível de ação) não se reporta diretamente a Iemanjá.

Para esta consideração, reporto-me à língua portuguesa falada no Brasil, pois nem sempre o som coincide com a grafia das palavras. $\mathrm{O}$ "e" pode ter som de "i", algumas vogais podem desaparecer, como no caso em questão: "roco" no lugar de rouco. Lacan mesmo chegou a utilizar esse procedimento para transcrever aquilo que se escuta, ou seja, de aproximar o que se escreve do significante que se escuta. Por exemplo, lom ao invés de l'homme [o homem] e em outras situaçóes abordadas no texto "Joyce le Symptôme" (Lacan, 1979).

$\mathrm{E}$ o adjetivo dourada remete à cor do fogo e também contém em si o anagrama da palavra duralo, que pode ser referido a Xangô, à rocha de onde a médium viu a águia saindo. Águia Dourada pode também se referir à Água Ígnea (sangue quente, lava vulcânica), o que cerne mais diretamente a questão do sujeito, pois, como a médium disse, a água que lhe concerne trata-se de uma "água vulcânica”, explosiva. Mar contém ar e ambos são regidos pelo fogo. Elegbara é o orixá que reina de fato. Tem-se assim, a eleição de um casal parental - espiritual Elegbara e Iansã, capaz de metaforizar e elaborar poeticamente posiçôes subjetivas da Barbara. 
O corte em volta simples na faixa de Moebius atesta que o ser escapa, um ser que nem se pode dizer ser já que é "ser em falta” e, ao se agarrar aos significantes, produz um sujeito dividido entre sentido (incompleto) e ser (perdido). Para além de todas as significaçóes possíveis derivadas de "fogo", há algo de sua cor, de sua intensidade, de seu brilho, de seu calor, de seu movimento, de seu estalido que remete a uma relação dinâmica, pulsional do sujeito, a uma parcela de não senso.

Enquanto real, "fogo" não se apresenta representativamente, mas como vazio organizador de operaçóes que ressoam no simbólico. Como o espaço é um constructo simbólico, no caso em questão a faixa de Moebius pode ser a apresentação espacial de uma subjetividade cujo cerne é este vazio que aparece principalmente em função do significante "fogo" tomado sobre o trajeto da linha que ata avesso e direito por toda a estrutura.

\section{Consideraçóes finais}

Uma vez que o objetivo deste trabalho foi propor uma aplicação da psicanálise a enunciaçóes sociais, recorreu-se a um caso ilustrativo da experiência de possessão. Por meio de um estudo de caso, mostramos como a topologia lacaniana possibilita a sua abordagem como um sistema em que não apenas se evidencia o caráter social da constituição do sujeito, como também o fato de não haver a mínima necessidade de distorcê-la em sintoma psíquico individual para poder lhe dar ouvidos e aceder ao seu sentido (pessoal em parte, mas sempre interpessoal e social).

Ao focarmos na operacionalidade do método psicanalítico e não somente no seu aparato conceitual, pudemos alargá-lo ao estudo de fenômenos considerados ao mesmo tempo em sua dimensão subjetiva e social (interpessoal), o que implica em dar ouvidos a uma história social, a um "outro coletivo" de forma que se perceba no desejo o desejo do Outro socialmente constituído e constituinte. Isto contribui para que a consideração do social em psicanálise ultrapasse o âmbito de um campo de especulaçóes e de ilustraçóes de natureza clínica para que ele possa aparecer tal como se mostra: no caso da possessão, um lugar efetivo de alteridade e de enunciação irredutível ao psiquismo particular.

Deste modo, o repertório metodológico já disponível em disciplinas como a antropologia, a sociologia, a história e a psicologia social para o estudo da possessão pode ser sofisticado com a aplicação da topologia lacaniana, que não apenas corrobora o entendimento de que diferentes "eus" podem conviver em um mesmo corpo, como também fornece meios de apresentar como essa relação se estrutura de modo contínuo. 
O dizer (inconsciente) configura um espaço moebiano onde "eu" e "outro" só são avesso e direito quando se toma um ponto sobre a faixa de Moebius. É somente pela adoção de uma perspectiva que se identifica a posição do sujeito da enunciação no campo do sujeito ou no do Outro. Como todo ato subjacente à enunciação revela uma faceta de desejo (sujeito) e outra de lei (Outro), mesmo que esta posição seja ocupada tanto pelo sujeito quanto pelo Outro, não se trata de uma concepção que o situe ora fora (Outro) ora dentro (sujeito), pois um campo implica o outro e desta maneira náo podem ser concebidos separadamente.

Os espíritos dizem sobre a pessoa por eles possuída (operando na função de "outro"), mas também narram um repertório social (referente à arquitetura simbólica, ao Outro), normalmente relegada a mero cenário ou contexto em análises de cunho psicológico. No entanto, uma vez que o sujeito é desde sempre social - por meio do idioma umbandista - não apenas se enuncia a singularidade da médium, como também particularidades referentes à Cabocla Águia Dourada e às caboclas em geral. $\mathrm{O}$ psiquismo encontra-se atrelado ao social.

Barbara só se dá conta do lugar que ocupa frente ao enigma de sua própria subjetividade no momento em que o dito (seja proferido por ela ou por esta entidade) opera um corte na (sua) estrutura. É a experiência do corte que revela uma organização subjetiva em torno de um vazio que repete de inúmeras maneiras o elemento "fogo", repetição esta que tece a teia significante cuja configuração é moebiana.

De modo mais amplo, a possessão mostra, pelo sistema de relações que a constituem, que a alteridade é constituinte do sujeito não como um meio de comparação ou afrontação egoica, mas como campo intrínseco a sua estrutura. Visto que sujeito e Outro fazem parte de uma mesma estrutura, topologicamente a questão da alteridade deve ser colocada em função do aspecto temporal (nela inserido), o que nos remete novamente à repetição significante.

\section{Referências}

Alberti, S. (1998). O pai no candomblé. Latusa, 2(1), 73-90.

Almeida, A. A. S, Oda, A. M. G. R., \& Dalgalarrondo, P. (2007). O olhar dos psiquiatras brasileiros sobre os fenômenos de transe e possessão. Revista de Psiquiatria Clínica, 34(1), 34-41. Recuperado em 18 de Junho de 2012, disponível na base de dados SciELO.

Augé, M. (1988). Le dieu objet. Paris: Flammarion.

Augras, M. (1983). O duplo e a metamorfose: a identidade mítica em comunidades nagô. Petrópolis: Vozes. 
Bairrão, J. F. M. H. (2004). O impossivel sujeito: implicações do tratamento do inconsciente, São Paulo: Rosari, v. 2.

Bairráo, J. F. M. H. (2005). A escuta participante como procedimento de pesquisa do sagrado enunciante. Estudos de Psicologia, 10(3), 441-446.

Bairrão, J. F. M. H. (2011). Nominação e agência sem palavras: o audível não verbal num transe de possessão. In F. V. Bocca, et al. (Orgs.). O movimento de um pensamento: ensaios em homenagem a Luiz Roberto Monzani (pp. 155-172). Curitiba: CRV.

Chemama, R. (1999). Onde se inventa o Brasil? Caderno da APPOA, 73, 10-18.

Crapanzano, V. (1977). Introduction. In V. Crapanzano \& V. Garrison (Eds.). Case studies in spirit possession (pp. 1-40). New York: Wiley.

Dolto, F. \& Nasio, J. D. (1991). A criança do espelho. Porto Alegre: Artes Médicas.

Ferreto, A. J. (1999). Outro: instruçóes de uso. Caderno da APPOA, 73, 19-29.

Fleig, M. (2003). Da possessão demoníaca à hipocondria. Caderno da APPOA, 116, 26-30.

Freud, S. (1974). Dois verbetes de enciclopédia: psicanálise e teoria da libido. In Edição standard brasileira das obras completas de Sigmund Freud, v. XVIII. Rio de Janeiro: Imago. (Trabalho original publicado em 1923)

Giumbelli, E. (1997). Heresia, doença, crime ou religião: o Espiritismo no discurso de médicos e cientistas sociais. Revista de Antropologia, 40(2), 31-82. Recuperado em 06 de junho de 2012, disponível na base de dados SciELO.

Godoy, D. B. O. A. (2012). Modelagem topológica da possessão: sujeito e alteridade na umbanda. (Tese de Doutorado. Faculdade de Filosofia Ciências e Letras de Ribeirão Preto, Universidade de São Paulo, Ribeirão Preto, S.P.).

Kracke, W. (2000). Algumas observações antropológicas sobre a psicanálise no Brasil. Les états généraux de la psychanalyse: Paris.

Lacan, J. (1998). Intervenções sobre a transferência. In J. Lacan. Escritos. Rio de Janeiro: Jorge Zahar. (Trabalho original publicado em 1951)

Lacan, J. (1998). Função e campo da fala e da linguagem em psicanálise. In J. Lacan. Escritos. Rio de Janeiro: Jorge Zahar. (Trabalho original publicado em 1953)

Lacan, J. (1995). O seminário, livro 11: os quatro conceitos fundamentais da psicanálise. 2a edição. Rio de Janeiro: Jorge Zahar. (Trabalho original de 1964)

Lacan, J. (2001). Radiophonie. In J. Lacan. Autres écrits. Paris: Édition du Seuil. (Trabalho original de 1970)

Lacan, J. (2001). L'Etourdit. In J. Lacan. Autres écrits. Paris: Édition du Seuil. (Trabalho original de 1972)

Lacan, J. (1979). Joyce le symptôme. In Joyce et Paris. Editions du C.N.R.S.

Lambek, M. (1981). Human spirits: a cultural account of possession in Mayotte. Cambridge: Cambridge University.

La Porta, E. (1979). Estudo psicanalitico dos rituais afro-brasileiros. Rio de Janeiro: Atheneu. 
Leiris, M. (1958/1996). La possession et ses aspects théâtraux chez les Éthiopiens de Gondar, précedée de la croyance aux génies zar en Éthiopie du Nord. In M. Leiris. Miroir de l'Afrique (pp. 949-1060). Paris: Gallimard.

Macedo, A. C., \& Bairrão, J. F. M. H. (2011). Estrela que vem do Norte: os baianos na umbanda de São Paulo. Paideia, 21(49), 207-216.

Moreira-Almeida, A., \& Cardeña, E. (2011). Diagnóstico diferencial entre experiências espirituais e psicóticas não patológicas e transtornos mentais: uma contribuição de estudos latino-americanos para o CID-11. Revista Brasileira de Psiquiatria, 33, 21-28. Recuperado em 15 de Junho de 2012, disponível na base de dados SciELO.

Pagliuso, L. \& Bairrão, J. F. M. H. (2010). Luz no caminho: corpo, gesto e ato na umbanda. Afro-Asia, 42, 195-225.

Prandi, R., \& Souza, P. R. (2001). Encantaria de mina em São Paulo. In R. Prandi (Org.) Encantaria brasileira: o livro dos mestres, caboclos e encantados (pp. 216-280). Rio de Janeiro: Pallas.

Quinet, A. (1989). Possessão e gozo. Isso: Despensa freudiana. Belo Horizonte.

Quinet, A. (2002). Um olhar a mais: ver e ser visto na psicanálise. Rio de Janeiro: Jorge Zahar. Vappereau, J.-M. (1988). Etoffe: les surfaces topologiques intrinsèques. Paris: Topologie en extension. Wolputte, S. V. (2004). Hang on to yourself: of bodies, embodiment, and selves. Annual Review of Anthropology, 33, 251-269.

\section{Notas}

${ }^{1}$ Há algumas exceçóes, como por exemplo Macedo e Bairrão (2011) e Pagliuso e Bairrão (2010).

${ }^{2}$ No artigo intitulado Dois verbetes de enciclopédia, Freud (1923/1974) define a psicanálise como "o nome (1) de um procedimento para a investigação de processos mentais que, de outra forma, são praticamente inacessíveis, (2) como um método (baseado nessa investigação) para o tratamento de distúrbios neuróticos e (3) uma coleção de informaçóes psicológicas obtidas ao longo dessas linhas, e que gradualmente se acumula em uma nova disciplina científica” (p. 287 - grifos nossos). Neste sentido, ressalta-se a importância de considerar a psicanálise como método de investigação do inconsciente.

${ }^{3}$ Para os fins a que este artigo se propóe, entende-se o termo "sujeito" em relação àquilo que aparece como efeito do dizer inconsciente.

${ }^{4}$ Topologicamente, pode-se entender o Outro como uma estrutura homeomórfica à linguagem que permite a ordenação em sequência de significantes atinentes à determinação de sentidos do sujeito (Lacan, 1970/2001). Deste modo, o Outro inclui tudo aquilo que concerne ao sujeito, inclusive a falta de sentido. 
${ }^{5}$ A escolha deste nome visa apresentar por meio de uma espécie de condensação simbólica um dos significantes que mais se repetiram com a médium (“ar”). Como na umbanda o orixá Iansã (vento) é sincretizado com Santa Barbara, abarcando ar também em sua grafia e vocalização, este me pareceu um bom nome para referir a médium.

${ }^{6}$ Para todos os efeitos práticos, embora não idêntico nem se admita a redução do Outro a algo empiricamente dado, o mundo dos espíritos opera como Outro genérico no universo da possessão. $\mathrm{O}$ argumento que justifica essa ideia é a compreensão de que o Outro, na possessão, por ser homólogo às possibilidades do universo espiritual, especifica-se nesse sistema simbólico. Por isso, abreviadamente, sem que se trate de uma proposição, identificação ou redução, pode-se dizer, sem contudo afirmar que o Outro é o mundo dos espíritos, ou seja, este se configura como a alteridade fundamental capaz de consubstanciar e singularizar algumas de suas possibilidades numa cosmovisão e sistema simbólico-religioso.

${ }^{7}$ De modo geral, "os encantados são espíritos de pessoas que um dia viveram e que não morreram, mas se 'encantaram', passando a existir no 'mundo invisível', do qual retornam ao mundo dos homens no corpo de seus iniciados, em transe ritual” (Prandi \& Souza, 2001, p. 217-218); ou seja, a característica fundamental da encantaria é a transmutação em outro ser que pode ser um animal, uma planta, um fenômeno da natureza entre outros.

${ }^{8}$ Não se trata propriamente de um sonho, a médium relata uma experiência de estado alterado de consciência como se ela tivesse saído do corpo, porém podemos supor neste episódio uma concatenação similar à estrutura do sonho.

Recebido em 24 de julho de 2012 Aceito para publicação em 12 de fevereiro de 2013 